\title{
Financial Distress Prediction Models in Property Sector Companies Listed in Indonesia Stock Exchange
}

\author{
Meita Tri Herlina and Werner Ria Murhadi \\ Department of Management, Universitas Surabaya, Surabaya \\ e-mail: meitatriherlina@yahoo.com
}

\begin{abstract}
Along with the unstable national and global economic conditions, investors and consumers defend themselves to invest in the property sector. Companies go public in obtaining capital markets as a means to obtain sources of funds. Investors and creditors will see the financial condition required before the company will increase financial distress (financial distress) or not before investing their capital. Therefore, analysis and prediction of a company's financial problems is very important. This study uses the Financial Distress model by using discriminant analysis. The independent variables used are financial ratios which are divided into 4 categories (1) Liquidity Ratios, (2) Solvency Ratios, (3) Activity Ratios, (4) Profitability Ratios. This research uses quantitative with the Multivariate Discriminant Analysis (MDA) model. The sample data used in this study includes property, real estate, and construction sector companies listed on the Indonesia Stock Exchange in the 20142018 period. This study produces a financial distress model Zscore $=-3,569+6,910 \mathrm{DTA}-1.107 \mathrm{DTE}+7,515 \mathrm{ROE}+$ $3,5730 P M$ with a cut-off value of $-3,521$. When the z-score of the company $<-3,521$ then the company is included in the group that changes financial difficulties, conversely if the z-score of the company> $-3,521$, the company is included in the nonfinancial pressure group.
\end{abstract}

Keywords-Multiple Discriminant Analysis (MDA), Financial Distress, Property Sector.

\section{INTRODUCTION}

$\mathrm{A}$ LONG with the unstable national and global economic conditions, investors and consumers refrain from investing in the property sector. In fact, the property sector is a locomotive of development in a country, many industries develop because they participate in supporting the property sector The property sector has a significant impact on financial products. If there is an increase in property prices that are too high, then market demand will decrease, resulting in a decline in growth in the property sector, the impact on the banking sector, especially in channeling housing loans (mortgage) will also experience a decline in growth. In addition, this sector has a multiplier effect and backward linkage that impacts other sectors. This is because the property sector is a labor-intensive sector and has several sectors involved. Based on UI studies there are at least 174 industries involved in it such as cement, paint, brick, furniture, iron, household electronics, besides that the property sector is also able to create jobs for the wider community.

In Indonesia, the property sector experienced a slowdown in sales growth from the end of 2014 to the beginning of
2018. Although demand for property at the end of 2018 increased, the US Trade policy created tensions in the world and caused 2019 to enter a state of uncertainty. Moreover, the increasingly severe macroeconomic conditions, slowing economic growth up to the trend of benchmark interest rates and liquidity that will be increasingly tight in 2019. In addition, political conditions in Indonesia are experiencing uncertainty, where in 2019 there will be general elections, making investors hesitate to invest. Companies go public utilizing the capital market as a means to get funding. The capital market can be used as a tool to reflect on the company's financial performance and condition. The market will give a positive response through an increase in the company's stock price if the financial condition and company performance are good. Investors and creditors will see the company's financial condition first whether the company will experience financial difficulties (financial distress) or not before investing.

Financial distress is the stage of declining financial conditions in a company before bankruptcy [1]. For this reason, an early introduction to the condition of companies experiencing financial distress is important. Financial distress conditions can be identified earlier before they occur by using an early warning system model. Therefore, analysis and prediction of a company's financial condition is very important [2]. Financial distress can be measured using financial statements by analyzing financial ratios. There are five types of ratios that can be used to analyze financial distress, namely liquidity ratio, profitability ratio, solvency ratio, Some models for predicting financial distress problems are the Altman model, Springrate and the Zmijewski model. The three analytical models are known for being not only easy but also because of the accuracy in determining financial distress predictions.

In a study conducted by Marcimkevicius and Kanapickiene used a total of 26 variables. To generalize, the analysis of each bankruptcy prediction model mentioned above in the Lithuanian construction sector company revealed that the Springate discriminant model and Chesser's Model logistic regression showed the highest and most accurate bankruptcy probability for determining bankruptcy predictions. Where Sringate has an accuracy rate of $86.94 \%$ and Chesser $92.70 \%$. While Zevgren has an accuracy rate of $77.35 \%$ and Altman $74.47 \%$. Whereas the Taffler \& Tisshaw model has the lowest accuracy rate of $42.99 \%$. This sample was carried out in the construction sector in Lithuana. 
The $1^{\text {st }}$ International Conference on Business and Engineering Management (IConBEM 2020)

February $1^{\text {st }} 2020$, Institut Teknologi Sepuluh Nopember, Surabaya, Indonesia

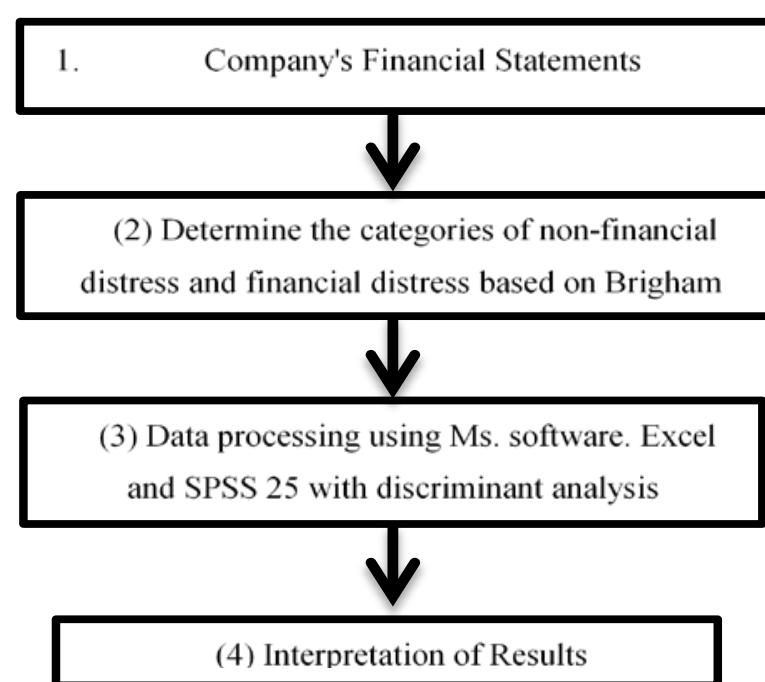

Figure 1. Steps of the Analysis Method.

Berzkalne and Zelgalve conducted research on companies registered in the Baltic using 35. From the research conducted by Berzkalne and Zelgalve, it is known that the highest accuracy of bankruptcy prediction models is the Zmijewski model where type II has an average error height (2002-2011 period) by 9\%. Whereas for other models, the accuracy rate is not good, with an average error rate for the Alman Z model at $38 \%$, the Altman Z 'model at $24 \%$, the Altman $\mathrm{Z}$ "model at $24 \%$, the Fulmer model at $53 \%$, the Springate model at 53\%, and the Sorins / Voronova model is $58 \%$. This sample was carried out in the construction sector in Lithuana.

Whereas Lin uses five variables from the Altman model in his research on the UK market. Obtained a low level of accuracy in the study that is equal to $64 \%$. After the researchers updated the coefficient of the Z-Score model and found that one of the variables (Sales / Total assets) was not significant in the study an accuracy increase of $24 \%$ was obtained, even though the level of accuracy was not as good as claimed by Altman at $97 \%$. This study provides evidence that the Altman Z-Score does not apply to the consumer goods industry.

Research conducted by Hapsari uses 4 variables namely CA / CL, NI / TA, NI / S, and CL / TA. In this study, there is no effect of current ratio and profit margin on sales on the financial distress conditions in manufacturing companies listed on the Indonesia Stock Exchange in the 2007-2010 period. While return on total assets and current liabilities of total assets have an influence on financial distress conditions in manufacturing companies listed on the Indonesia Stock Exchange in the 2007-2010 period, because the results of the hypothesis show that the variable has a significant effect with a negative regression equation.

Based on the above studies it has been proven empirically that financial ratios can be used to form a company's financial distress prediction model quite accurately. Existing financial distress models were made in various countries, such as the Altman and Zmijewski models using company research samples found in the United States, while Springate conducted research on companies located in Canada. In
Marcikevicius and Kanapickene's research in the construction sector in Lithuania using 5 Financial Distress prediction models, the highest accuracy level was concluded by the Chesser 92.70\%, Springate 86.94\%, Zevgren $77.35 \%$, Altman $74.47 \%$, and Taffler \& Tisshaw $42.99 \%$. Then there are studies conducted by Berzkalne and Zelgalve in Lithuania in the construction sector, using 6 models that have different levels of accuracy namely Altman Z 38\%, Altman Z '24\%, Altman Z "24\%, Fulmer 53\%, Springate 53 $\%$, and Sorins / Voronova 58\%. From the research conducted by Lin using the Altman model in his research in the UK, obtained a low level of accuracy in the study of $64 \%$. Besides that it is proven that the Altman Z-Score does not apply to the consumer goods industry.

From these studies it is known that the prediction models used in different sectors and countries have different levels of accuracy as well. In addition, in the research conducted

by Lin, it was found that one of the variables (Sales / Total Assets) was not significant in the study. Therefore, researchers want to create prediction models based on research objects in Indonesia using Liquidity Ratio, Leverage Ratio, Activity Ratio, and Profitability Ratio. The object chosen is the property sector, where this sector is a sector that has an important role in the national economy and is a primary need for the community.

\section{METHOD}

\section{A. Research Types and Data Sources}

This type of research is applied research that is research to develop research that has been done before. This study also includes quantitative research that is research that uses numbers, with the object of research is the company's financial condition in the property sector in Indonesia which is listed on the Indonesia Stock Exchange in the 2014-2018 period. Data collected from this research are secondary data. Sources of data in this study are from various sources of books, journals and previous studies that support research. As for the data source that will be processed in a research analysis from www.idx.co.id which is the official website of the Indonesia Stock Exchange.

\section{B. Method of Collecting Data}

To obtain relevant data that can be used as a basis in the analysis process, the authors use data collection techniques with the documentation study method, namely by collecting documents relating to financial distress and data relating to the characteristics of each company that becomes this research sample and other supporting data. Data collection techniques used in this study are; (1)Literature research is the collection of data and relevant information through reading and reviewing books, articles, journals, and data on company financial statements relating to the issues raised in this study; (2)Access websites and sites that provide information related to the problem in this study; (3)The data used in this study based on the available objectives uses secondary data in the form of financial statements from 31 property, real estate, and construction \& building companies 
The $1^{\text {st }}$ International Conference on Business and Engineering Management (IConBEM 2020)

February $1^{\text {st }} 2020$, Institut Teknologi Sepuluh Nopember, Surabaya, Indonesia

Table 1.

Kolmogorov Smirnov

\begin{tabular}{lll}
\hline & \multicolumn{2}{l}{ Kolmogorov Smirnov } \\
\hline \hline Variable & $\mathrm{N}$ & Asymp. Sig. (2-tailed) \\
\hline QR & 160 & 0.000 \\
CR & 160 & 0.000 \\
CuR & 160 & 0.000 \\
WCTA & 160 & 0.002 \\
OCF & 160 & 0.000 \\
DTA & 160 & 0.200 \\
DTE & 160 & 0.000 \\
LTDE & 160 & 0.000 \\
TIE & 160 & 0.000 \\
TATO & 160 & 0.000 \\
FATO & 160 & 0.000 \\
RTO & 160 & 0.057 \\
ITO & 160 & 0.000 \\
WCTO & 160 & 0.000 \\
PMS & 160 & 0.000 \\
ROA & 160 & 0.000 \\
ROI & 160 & \\
ROE & 160 & 0.000 \\
GPM & 160 \\
OPM & 160 & \\
\hline \hline
\end{tabular}

Table 2.

Box's M Test

Box's M

Sig.

on the Indonesia Stock Exchange (IDX) in the form of financial and annual reports in 2016-2018.

\section{Research Scopes}

The scope of research includes 33 property, real estate, and construction \& building sector companies registered in 2014 to 2018.

Data collection techniques used in this study are based on the existing objectives using secondary data in the form of financial statements from 33 companies in the property, real estate, and construction \& building sectors on the Indonesia Stock Exchange (IDX) in the form of financial and annual reports in 2014-2018 In addition to obtaining the data needed through the main activity that is library research from books, journal references and websites on the internet.

\section{Population and Sample}

The population in this study are all publicly listed companies listed on the Indonesia Stock Exchange. Sampling in this study uses a purposive sampling method that is the property sector, real estate, and construction \& buildings. Limitation of sample selection based on certain criteria. The criteria for sampling are: (1)Property, real
Table 3.

Test of Equality of Group Means

\begin{tabular}{ll}
\hline \hline \multicolumn{2}{c}{ Test of Equality of Group Means } \\
\hline QR & 0.649 \\
CR & 0.170 \\
CuR & 0.404 \\
WCTA & 0.699 \\
OCF & 0.390 \\
DTA & 0.035 \\
DTE & 0.231 \\
LTDE & 0.022 \\
TIE & 0.000 \\
TATO & 0.606 \\
FATO & 0.655 \\
RTO & 0.111 \\
ITO & 0.602 \\
WCTO & 0.715 \\
PMS & 0.029 \\
ROA & 0.000 \\
ROI & 0.054 \\
ROE & 0.000 \\
GPM & 0.040 \\
OPM & 0.000 \\
NPM & 0.000 \\
\hline \hline
\end{tabular}

estate, and construction \& building sector companies that are consistently listed on the Indonesia Stock Exchange; (2)Property, real estate, and construction \& building sector companies publish complete and audited financial statements for the period 31 December 2014 to 31 December 2018; (3)Property, real estate, and construction \& building companies listed on the Indonesia Stock Exchange that have complete data needed in this study.

\section{E. Operational Definition and Variable Measurement}

The dependent variable used in this study is financial distress. Financial distress is a stage of decline in financial conditions marked by a continuous decline in profits and a decrease in the amount of dividends distributed to shareholders for several consecutive periods. This variable is measured using a dummy variable with the category of companies experiencing financial distress marked " 1 " while non-financial distress companies are marked "0".

Criteria for companies included in the financial distress group "1" are companies that have negative net operating income for 2 consecutive years in the 2014-2018 period.

The independent variable used in the study is financial performance. Financial performance is an assessment of the financial condition of a company that requires analysis with several benchmarks such as ratios and indexes so that the two financial data can be connected between one another . Financial ratios are used to produce a company's financial distress model that consists of 21 financial ratios which fall 
The $1^{\text {st }}$ International Conference on Business and Engineering Management (IConBEM 2020)

February $1^{\text {st }} 2020$, Institut Teknologi Sepuluh Nopember, Surabaya, Indonesia

Table 4.

Box's M Test

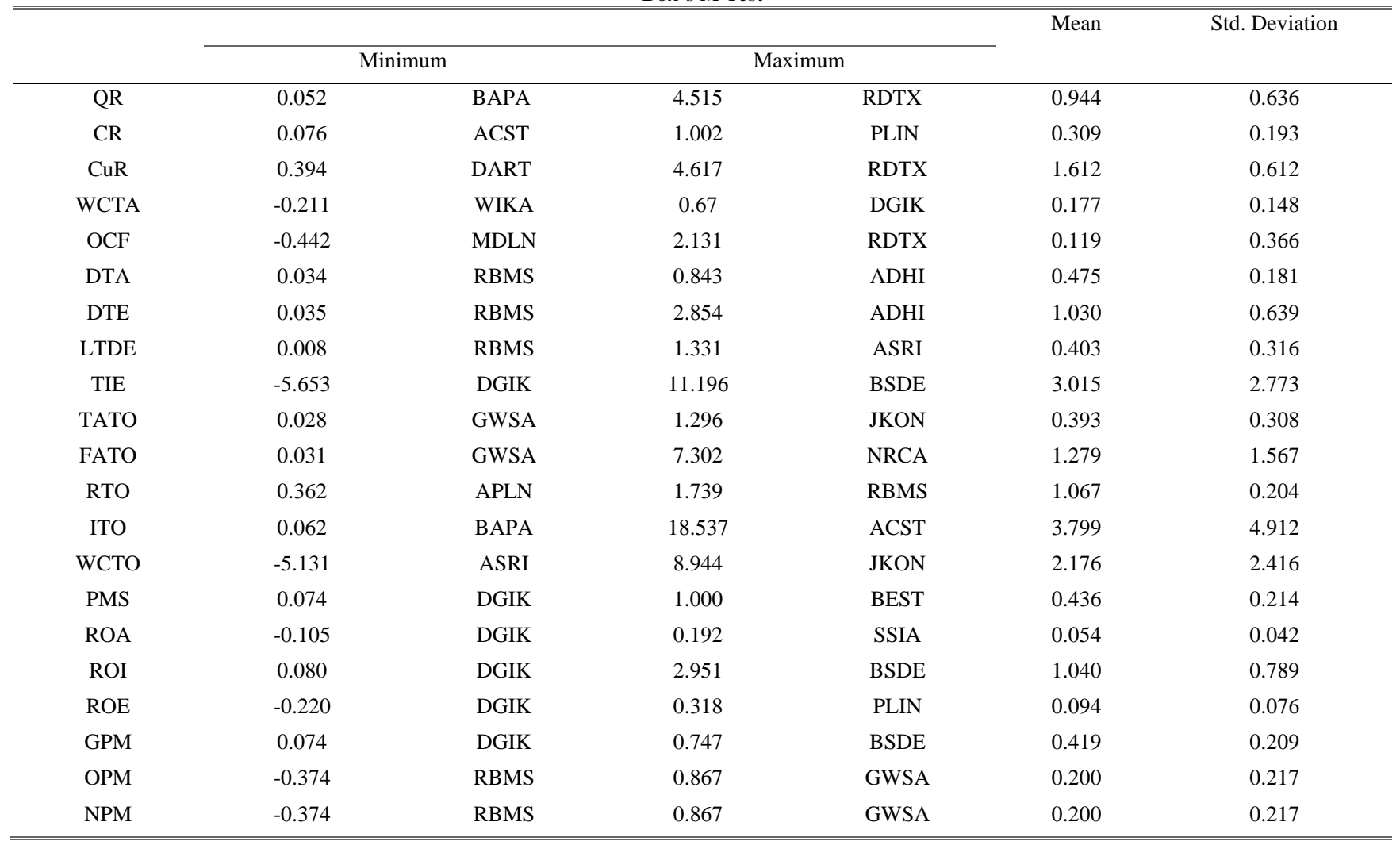

into 4 categories, namely (1) liquidity ratio, (2) leverage ratio, (3) activity ratio, and (4) profitability ratio. The dependent variables used in this study are (1) Bankrupt and (2) Non-bankrupt.

\section{F. Measurement Levels of Data}

The measurement level of data used in this study is financial ratios. The financial ratio level has all the characteristics possessed by the nominal, ordinal and interval levels plus the ability to carry out mathematical operations. This study aims to form a bankruptcy prediction model using mathematical operations to obtain results. The model uses dominant factors that influence the determination of the company's financial distress.

\section{G. Statistic Test}

\section{1) Normality Test}

The first step taken to produce a model that can be implemented is to fulfill the assumptions of discriminant analysis. The assumption that must be met is multivariate normality or independent variables should have normal distribution. If the data is not normally distributed, this will reduce the validity of the resulting discriminant model. To test the normality of data distribution in this study is to use the Kolmogorov-Smirnov test contained in the SPSS program. After conducting the test, the normality of the data will be known, by looking at the level of significance. If the significant level of data is less than $5 \%$, the data used are not normally distributed. However, if the significant level produced is greater than $5 \%$, then what is used is normally distributed data.

\section{2) Covariance Matrix Test}

The independent variable has no correlation between variables. If there is a strong correlation between independent variables, multicollinities will occur. Next, an assumption test will be conducted, namely the covariance matrix between independent variables must be the same and there is no correlation between the independent variables. From these two assumption tests we will obtain dominant financial ratios that can be used to form discriminatory analysis.

The principle of discriminant is wanting to create a model that can clearly show differences (discriminant) between the contents of the dependent variable, which in this study is the non-financial distress or financial distress group. For this reason, the first step in discriminant analysis is to test whether all independent variables differ markedly based on the dependent variable. Testing the variables in this study will be conducted Box's M Test. Box's M Test is performed to test the variance of each variable. Discriminant analysis has the assumption that: (1)Variance of free variables for each group should be the same. If so, the variance of companies that experience non-financial distress should be the same as companies that experience financial distress; (2)Variance among independent variables should also be the same. If so, the variance of the variables used in this study should be the same.

Box’s M variance test requirements:

(1) If sig $>0.05$ then $\mathrm{H} 0$ is accepted

(2) If sig $<0.05$ then $\mathrm{H} 0$ is rejected

(3) Hypothesis: 
The $1^{\text {st }}$ International Conference on Business and Engineering Management (IConBEM 2020)

February $1^{\text {st }} 2020$, Institut Teknologi Sepuluh Nopember, Surabaya, Indonesia

Table 5 .

Classification Results

\begin{tabular}{lccccc}
\hline \hline & & Y & Predicted Group Membership & Total \\
& & & 0 & 1 & \\
\hline Original & Count & 0 & 149 & 6 & 155 \\
& & 1 & 1 & 4 & 5 \\
& $\%$ & 0 & 96.1 & 3.9 & 100 \\
& & 1 & 20.0 & 80.0 & 100 \\
Correctly Classified & & & & 153 & $96 \%$ \\
Miss Classified & & & & 7 & \\
\hline \hline
\end{tabular}

(1) H0 = variance of both homogeneous / equal groups

(2) H1= variance between the two heterogeneous / unequal groups

\section{3) Hypothesis Testing}

The hypothesis used in this study is as follows

(1) H0 = Financial ratios can be used to form Financial Distress prediction models

(2) H1 =Financial ratios cannot be used to form Financial Distress prediction models

Hypothesis testing can be seen in the value of Canonical Correlation in Eigenvalues Table, if the significant value $<0.05$ then the independent variables used are able to distinguish the grouping of companies that experience financial distress and non-financial distress.

(1) $\mathrm{Sig}<0.05=\mathrm{H} 0$ received

(2) $\mathrm{Sig}>0.05=\mathrm{H} 0$ is rejected

\section{H. Data Analysisi Method}

The data analysis method used in this study is Multiple Discriminant Analysis. Namely the analysis using multivariate techniques included in the dependence method, characterized by the presence of independent and dependent variables. Thus, there are variables whose results depend on the independent variable data. A special feature of discriminant analysis is that the dependent variable data must be in the form of categorical data, while the data for the independent variables are in the form of ratios. The purpose of discriminant analysis is as follows; (1)Find variables that differ significantly between the two groups; (2)Arrange an equation or function to calculate the index value that will represent exactly the difference between the two groups; (3)Use the calculated index as a guide to classify further observations into one of these groups.

Discriminant analysis is one of the techniques used in research involving multiple measurements. As said by Johnson and Wichem (2002: 461) "discriminant analysis are multivariate techniques concerned with separating distinct sets of objects (or observation) and with allocating new objects (observations) to previously defined groups".The steps taken in testing are in Figure 1. Image Figure 1: (1)Data source processed, 2016; (2)Determine the categories (non-financial distress and financial distress) or predict each company based on Brigham and Houston theory, namely the value of operating profit. If the operating profit value is negative, then the company will experience financial distress. According to Ramdhani and Lukviarman (2009), bankruptcy of a company is characterized by financial distress, which is a situation where the company is weak in generating profits; (3)Data processing using SPSS software version 25 using discriminant analysis; (4)Interpretation of the Results.

The results of data processing using Ms. software. Excel and SPSS version 25 with discriminant analysis produce the equation of the Financial Distress Prediction model. Financial reports are used to measure, find out, and illustrate the possibility of financial distress in property, real estate, and construction \& building companies. The overall data of the financial statements of the property, real estate, and construction \& building sector companies collected were then analyzed to be able to provide answers to the problems discussed in this study.

The first step is to group the population into two groups based on the company's operating profit which has a negative value as a group of companies that experience financial distress and a group of non-financial distress companies. This grouping is used to conduct discriminant tests in order to obtain predictive models that are formed from dominant ratios.

After obtaining a discrete model, z-scores of companies experiencing financial distress and non-financial distress will also be obtained by calculating a single cut-off score. After the discriminant analysis model is obtained, the last step is to implement the model in property and real estate companies listed on the Indonesia Stock Exchange in the 2014-2018 period. From the implementation will be obtained by companies that are included in the group "experiencing financial distress" and "not experiencing financial distress". This research produces a model in the form of:

Z-score $=-3,569+6,910 \mathrm{DTA}-1.107 \mathrm{DTE}+7,515 \mathrm{ROE}+$ 3,573OPM

If the data used does not meet one or more of the MDA requirements described earlier, the analysis method switches to the logistic regression model.

\section{RESULT AND DISCUSSION}

The first step taken is to test data normality using the Kolmogorov Smirnov test (table 1). Based on the results of normality tests that have been done, obtained 2 ratios that are normally distributed, namely DTA of 0.200 , and RTO of 0.057 . While 19 ratios are not distributed because they have a significant value $<0.05$, namely WCTA of 0.002 , CuR of 0.008 , OCF of 0.008 , ROA of 0.041 , ROE of 0.018 , and some ratios have a significant value of 0,000 namely $Q R$, CR, DTE, LTDE, TIE, TATO, FATO, ITO, WCTO, PMS, ROI, GPM, OPM and NPM.

Twenty-one financial ratios can be used even though there are ratios that are not normally distributed, because this can be justified based on the Central Limit theorem proposed by Gujarati and Zain (1978: 66) which states that with a large amount of data that is $n>30$, data with itself will be normally distributed. Because the data used in this study amounted to 160 in each variable so that by itself the data will be normally distributed.The results of the Box's $M$ (table 2) test have a significant value of 0.009 , it can be concluded that the covariance matrices between groups 
The $1^{\text {st }}$ International Conference on Business and Engineering Management (IConBEM 2020)

February $1^{\text {st }} 2020$, Institut Teknologi Sepuluh Nopember, Surabaya, Indonesia

differ because $<0.05$, but the discriminant analysis remains robust even though the assumption of homogeneity of variance is not fulfilled because outlier data have been issued in accordance with Ghozali (2001).

In Table 3. Test of Equality of Group Means, discriminant analysis is divided into 2 groups namely, groups of financial distress companies and non-financial distress companies. This table serves to test whether there are significant differences between groups for the independent variables used. Independent variables that are not able to distinguish between groups of companies that experience financial distress and non-financial distress are QR, CR, CuR, WCTA, OCF, DTE, TATO, FATO, RTO, WCTO, ROI. While the independent variables that are able to distinguish groups of companies that experience financial distress and non-financial distress are DTA, LTDE, TIE, ROA, ROE, GPM, OPM and NPM.

From the results of discriminant analysis that have been done, it is known that there are 4 dominant ratios in determining the group of financial distress and non-financial distress, namely the ratio of Debt to Total Assets, Debt to Equity, Return on Equity, and Operating Profit Margin. With the discriminant function:

Z-score $=-3,569+6,910 \mathrm{DTA}$-1.107DTE + 7,515ROE + 3,573OPM

The discriminant model shows the ratio of DTA, ROE, and OPM has a positive effect. This means that if the ratio of DTA, ROE, and OPM owned by the company is getting bigger, the healthier the company (non-financial distress). While the DTE ratio has a negative influence, meaning that if the ratio of the company is getting smaller, the more unhealthy the company (financial distress). The resulting single cut-off is $-3,521$, if the $\mathrm{z}$-score is greater than $>$ 3,521 , the company is included in the non-financial distress group.

From the results of discriminant analysis, it is known that there are two dominant ratio groups in determining companies that are included in financial distress and nonfinancial distress, namely leverage ratio (DTA and DTE) and profitability ratio (ROE and OPM). Debt to Total Assets (DTA) ratio can affect the financial distress model because it measures how much the company's assets are financed by debt or how much the company's debt affects the asset management. The greater the value of the DTA ratio, the greater the amount of loan capital used to invest in assets in order to generate profits for the company and the smaller the number of assets financed by capital, the higher the risk of the company to pay off its long-term obligations and the higher the burden of debt interest must be borne by the company.

In Table 4. it can be seen that the DTA value of the company's sample ranges from 0.034 to 0.843 . This means that assets owned by the Property, Real Estate and Construction sector companies are financed by debt of 3.4\% to $84.3 \%$. DTE can influence the financial distress model because DTE is used to assess a company's financial position, this ratio is also to measure the company's ability to pay off its obligations. In the discriminant results it is known that DTE has a negative influence on the level of financial distress. This is not in accordance with the theory that DTE has a positive influence on the level of financial distress. But these results are in line with research conducted by Tanuwijaya in the 2018 Murni journal, which states that DTE has a negative influence on the level of financial distress. This can occur. Companies with a decision to use debt in their balance sheets in general can increase their profitability, which can then increase their share prices, thereby increasing the welfare of shareholders and can build greater growth potential and reduce the potential for financial distress.

ROE can affect the financial distress model because it is used to measure the company's ability to obtain profits available to shareholders. In Table 4. the ROE value of the property sector ranges from -0.220 to 0.318 . The ROE value of the property sector on average approaches 0 , meaning that companies in the property sector are unable to manage available capital efficiently to generate revenue. This ratio is also influenced by the company's debt, if the proportion of debt is greater then this ratio is also getting bigger. In the results of discriminant analysis it is known that ROE has a positive influence on financial distress, this is contrary to existing theories. This can occur because high ROE has problems with the inconsistency of the company's earnings, so that losses in the past can reduce the equity of shareholders. Then when a company makes a sudden profit in the last year and makes a profit it causes the denominator in the ROE calculation formula to be very small after losing for years, so the higher ROE can be misleading. The second cause is because the company is over debt. If a company has aggressive debt, this can increase ROE. A common factor causing this to happen is when a company borrows large amounts of debt with the aim of buying its own shares. So that earnings per share (EPS) can increase, but on the other hand it cannot affect the actual growth rate or performance of the company [3].

OPM ratio can affect the discriminant model because OPM is used to find out how much the amount of operating profit generated compared to sales. The higher the value of OPM can increase the value or price of a stock. In Table 4. The OPM values are -0.374 to 0.867 . From Table 5 it can be seen that there are companies that experience losses but there are also companies that have OPM 0.867 (RBMS) or $86.7 \%$. Based on the results of discriminant analysis it is known that OPM has a positive influence on financial distress. Of course this contradicts existing theories, but this can occur because the higher OPM ratio means that each rupiah of sales absorbed in costs is also high, and that is available for small profits. The greater changes in operating profit margins indicate greater fluctuations in management's ability to generate operating profit [4].

At the beginning of the classification, companies that experienced financial distress had the criteria of the company to have negative net income for one year in a row. There are 5 companies included in the financial distress group at the beginning of the classification, namely DGIK 2016-2018 and RBMS 2015-2016. After implementing financial distress, 3 companies were predicted to experience financial distress, namely DGIK 2016, and RBMS 2015- 
The $1^{\text {st }}$ International Conference on Business and Engineering Management (IConBEM 2020)

February $1^{\text {st }} 2020$, Institut Teknologi Sepuluh Nopember, Surabaya, Indonesia

2016. From this data it shows that there are 3 companies that remain in the group of companies that experience financial distress according to the initial classification, namely DGIK 2016, and RBMS 2015-2016. The results of the implementation in the Property, Real Estate, and Construction sectors for the 2014-2018 period show that there are all companies that are included in the financial distress category in the financial distress category at the beginning.

The accuracy of the resulting financial distress prediction model is $96 \%$. Because the accuracy of the discriminant model produced is high $>50 \%$, this discriminant model can be used to predict financial distress in the property, real estate and construction sectors. The results of discriminant analysis in this study can be seen that the independent variables are used as variables in forming financial distress prediction models and produce the function:

Z-score $=-3,569+6,910$ DTA -1.107 DTE + 7.515 ROE + 3,573 OPM.

From the resulting model it can be seen that the ratio of DTA, ROE, and OPM has a positive effect. This means that if the ratio of DTA, ROE, and OPM owned by the company is getting bigger, the healthier the company (non-financial distress). While the DTE ratio has a negative influence, meaning that if the ratio of the company is getting smaller, the more unhealthy the company (financial distress). In the initial classification based on negative net income criteria two years in a row from 160 companies in the Property, Real Estate and Construction sector in the 2014-2018 period there were 5 companies included in the financial distress group namely DGIK 2016-2018 and RBMS 2015-2016. While the results of the implementation showed that there were 3 companies that experienced financial distress, namely DGIK 2016, and 2015-2016 RBMS. This shows that the model can classify 3 out of 5 companies that experienced financial distress in the initial classification, meaning that the accuracy of the discriminant model resulting from this study can be known to be $96 \%$.

\section{REFERENCES}

[1] M. . Platt, H. \& Platt, "Predicting financial distress," J. Financ. Serv. Prof., vol. 56, no. 3, pp. 12-15, 2002.

[2] S. Atmini and W. Andayani, "Manfaat laba dan arus kas untuk memprediksi kondisi financial distress pada perusahaan textile mill products dan apparel and other textile products yang terdaftar di bursa efek jakarta,” J. TEMA, vol. 8, pp. 460-474, 2005, doi: 10.18202/TEMA.V7I2.148.

[3] A. R. Qoribulloh, "R. Qoribulloh, "Pengaruh rasio keuangan terhadap harga saham pada perusahaan manufaktur yang terdaftar di bursa efek indonesia tahun 2011,” Universitas Yogyakarta, 2013.

[4] R. dan M. F. Daud, "Pengaruh operating profit margin, dividend payout ratio, profitabilitas, dan price earning ratio terhadap praktik perataan laba pada perusahaan lq-45 yang terdaftar di bursa efek indonesia tahun 2010-2014," J. Akunt. Muhammadiyah, vol. 8, no. 1, 2017. 